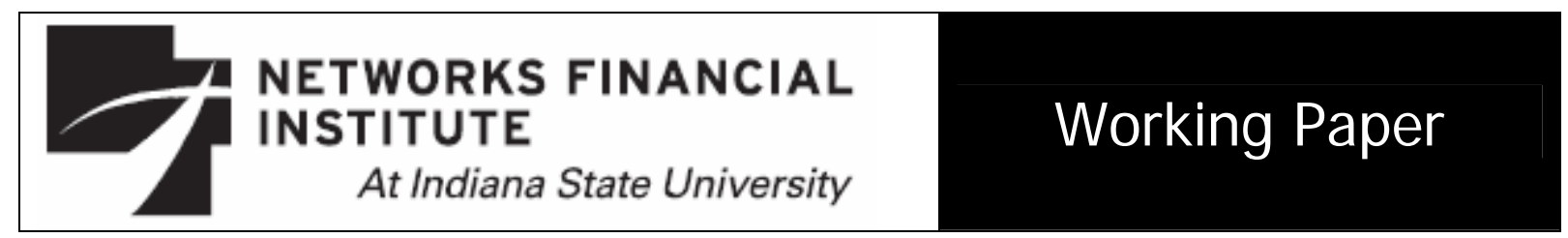

2008-WP-06

J une 2008

\title{
Pension systems generosity in North Africa
}

\section{Mehdi Ben Braham}

Abstract: Pension systems in North Africa are facing a certain number of difficulties. We present in this paper the pension system's characteristics and organization in Algeria, Morocco and Tunisia. This work identifies the specificities, as well as the common problems, of each country's pension system. Using the actual pension system authorizing legislation and case simulations, we analyze the high degree of generosity of the different systems and its sources. This generosity cannot be maintained in a context of aging populations. Reform is needed. Finally, we discuss the different ways to reform the systems, the possibility of reform applications and their macroeconomic impacts.

About the Author: Mehdi Ben Braham received his B.A. in economics from the University of Tunis II, and a Master's degree and Ph.D. in economics from the University Paris Dauphine. His research areas include aging populations, pension reform, financial development and economic growth. He is working on pension funds introductions and their impacts on financial markets and economic growth in emerging countries. Dr. Ben Braham has participated in several conferences on pension reform and their macroeconomic impacts, particularly on emerging countries and Middle East and North Africa (MENA) countries. Dr. Ben Braham has worked on pension reform in emerging countries in the retirement research department of La Caisse des Dépôts et Consignations in Paris and has taught microeconomics at Dauphine University and macroeconomics in INSEEC (Paris), the Institute of Economic Sciences and Management. He completed a postdoctoral position at University Paris Dauphine, where he worked on a European project on aging populations, health expenditures evolution and social security reform. Currently, he is teaching microeconomics in a public High School of Management in Tunisia.

Keywords: Retirement, Reform, Algeria, Morocco, Tunisia

\section{J EL Codes: J 26}

The views expressed are those of the individual author and do not necessarily reflect official positions of Networks Financial Institute. The author thanks J ohn A. Tatom for his remarks. Please address questions regarding content to Mehdi Ben Braham at benbrahammehdi@yahoo.com. Any errors or omissions are the responsibility of the author.

NFI working papers and other publications are available on NFI's website (www.networksfinancialinstitute.org). Click "Research" and then "Publications/Papers." 


\section{Introduction}

The future of pension systems and their financial viabilities in the North African countries of Algeria, Morocco and Tunisia are main topics in their respective government debates. The World Bank has recently issued a report on pension regime futures in the MENA region (Robalino, 2005). Despite geographical proximity, economic structures and pension systems are different throughout North Africa. Even if pension systems in this region are often analyzed together and despite common characteristics, they are suffering from different problems and their future financial viability is affected by different factors. Generosity of these pension systems, which is one common point characterizing the three countries, is analyzed. Results will allow us to identify the source of generosity and therefore help us to suggest some ways to reform these pension systems.

Part one will present pension systems in the three countries (Algeria, Morocco and Tunisia). We will focus on system organization and legislative provisions. The weakness of pension systems in each country will be presented. In the second part, using each country's legislation, we simulate fictive careers and calculate generosity indicators of the most important pension regimes in each country. Results allow us to make intra- (between local regimes) and international (between the three countries) comparisons in terms of generosity. Part three takes into account each country's characteristics. We analyse different ways to reform the systems in order to insure the same level of pension to future retirees and maintain financial equilibrium for the retirement system.

\section{Pension systems in Algeria, Morocco and Tunisia}

The pension systems in the three countries are similar in their structure. They work as "Pay-as-you-go" (PAYG) systems: workers at period " $\mathrm{t}$ ” pay the retirees' pensions of the same period. The systems often distinguish between private and public sector workers, or employees and self-employed. Despite these common points, the socioeconomic environments are very different in the three countries. These differences have important effects on the problems that each pension system could face.

\section{A. Algerian pension system}

The Algerian system is a PAYG one with a recent objective to establish adequate funding. A reserve fund was created in July 2006. Funds come from a transfer of 2 percent of the "energy" tax resources. The system is constituted by two regimes: 
- The CASNOS (Caisse Nationale de Sécurité Sociale des non-salariés): created in 1958, it serves all self-employed workers.

- The CNR (Caisse Nationale de Retraite): it covers employees from the public and private sectors.

Table 1: Pension system legislation in Algeria

\begin{tabular}{|c|c|c|}
\hline & CNR & CASNOS \\
\hline Age condition & 60/55 years (Man/Woman) & 65/60 years (Man/Woman) \\
\hline Minimum contribution period & 15 years & 15 years \\
\hline Contribution rate & 10.25\% (employer)+7\% (employee) & $15 \%$ \\
\hline $\begin{array}{l}\text { Pension calculation (reference } \\
\text { wage) }\end{array}$ & $\begin{array}{l}\text { Average wage of the last five years } \\
\text { preceding the retirement date. }\end{array}$ & $\begin{array}{l}\text { Best } 10 \text { yrs w/ maximum of } 8 \\
\text { MWG (Minimum Wage } \\
\text { Guaranteed) }\end{array}$ \\
\hline Annuity rate & \multicolumn{2}{|l|}{$2.5 \%$ per year } \\
\hline Minimum pension & \multicolumn{2}{|l|}{$75 \%$ of the MWG } \\
\hline Maximum pension & $\begin{array}{l}80 \% \text { of the declared wage and } 15 \\
\text { times the MGW }\end{array}$ & $80 \%$ of the declared wage \\
\hline Pension revalorization & \multicolumn{2}{|c|}{ Indexed on wages until 1999, fixed by CMR administrators } \\
\hline
\end{tabular}

The CNR financial situation is much better than the CASNOS one. By increasing its contribution rate during the last ten years, the CNR regime succeeded in maintaining financial equilibrium and accumulating a reserve. On the other hand, CASNOS is characterized by an important deficit, explained in part by a decrease of the dependency ratio from 2.1 in 2002 to 1.54 in 2006. The generosity of the system, population aging and the cover rate decrease account for the CASNOS deficit.

The pension system in Algeria will, in the near future, face the consequences of population aging as well as an unemployment rate problem, a large informal sector (35 percent of GDP in $2006^{1}$ ) and a high degree of generosity. Even if the government calculations rely on energy taxes, a significant reform is needed to avoid a serious financial crisis of the pension system.

\section{B. Moroccan pension system}

This system is divided into 4 regimes:

\footnotetext{
${ }^{1}$ African Development Bank, Perspectives Economiques en Afrique, note on Algeria (2007).
} 
- The CNSS (caisse nationale de sécurité sociale): it covers employees of the private sector in industry and commerce and self employed as artisans or in agriculture and fishing. The system is mandatory for employees and employers.

- The CMR (caisse marocaine des retraites): created in 1930, it covers three types of workers: civil and military state employees, employees of local political units, and employees of certain public establishments.

- The RCAR (régime collectif d'allocation de retraite): it concerns two types of workers: non-permanent state workers and employees of public units under state financial control.

- $\quad$ The CIMR (caisse interprofessionnelle marocaine de retraite): a complementary regime for the CNSS contributors.

Table 2: Pension system legislation in Morocco

\begin{tabular}{|c|c|c|c|c|}
\hline & CNSS & CMR & RCAR & CIMR \\
\hline & mandatory & mandatory & mandatory & voluntary \\
\hline & PAYG & PAYG & $\begin{array}{l}\text { 2/3 capitalized, 1/3 } \\
\text { PAYG }\end{array}$ & $\begin{array}{l}\text { PAYG with reserve } \\
\text { component }\end{array}$ \\
\hline Contribution rate & $11.89(1 / 3 ; 2 / 3)$ & $20 \%(50 \%-50 \%)$ & $18 \%(2 / 3 ; 1 / 3)$ & Between 6 and 13\% \\
\hline Retirement age & $\begin{array}{l}60 \text { years with } 15 \\
\text { years of contribution }\end{array}$ & 60 years & 60 years & 60 years \\
\hline $\begin{array}{l}\text { Maximum of } \\
\text { declared wage }\end{array}$ & $6000 \mathrm{DH}$ & none & $11700 \mathrm{DH}$ & 100436DH \\
\hline Pension calculation & $\begin{array}{l}50 \% \text { of the average } \\
\text { wage of the last } 8 \\
\text { years (without } \\
\text { indexation) plus } 1 \% \\
\text { for each } \\
\text { supplementary year. }\end{array}$ & $\begin{array}{l}2.5 \% \text { of the last } \\
\text { wage for each } \\
\text { contribution year }\end{array}$ & $\begin{array}{l}2 \% \text { of the career } \\
\text { average wage } \\
\text { (indexed by wage } \\
\text { evolution) for each } \\
\text { contribution year. }\end{array}$ & $\begin{array}{l}\text { System working by } \\
\text { points }\end{array}$ \\
\hline Maximum pension & $\begin{array}{l}70 \% \text { of the average } \\
\text { wage }\end{array}$ & $\begin{array}{l}100 \% \text { of the last } \\
\text { wage }\end{array}$ & $\begin{array}{l}90 \% \text { of the average } \\
\text { wage }\end{array}$ & none \\
\hline Minimum & $500 \mathrm{DH}$ & $\begin{array}{l}\text { 500DH for } 5 \text { years } \\
\text { of contribution }\end{array}$ & none & none \\
\hline
\end{tabular}

The pension system in Morocco suffers from three important problems: the first one is the cover rate, which is very low compared to Algeria and Tunisia (see Table 2). A very low part of the active population contributes to the pension system and only a small number of aged people receive a pension, as well. Graph 1 shows this situation and shows precisely a lower cover rate for young workers in the CMR in the 30-34 age class. We can see that only 7 percent of the active population in the first age class is contributing to the pension system. These results are very important to underline since they constitute a problem specifically in Morocco (compared to Algeria and Tunisia) and will create a serious problem of poverty for the aged population. The risk of being without resources in the retirement period is not really 
covered. Social protection, especially in rural regions, is handled via informal mechanisms like family help.

\section{Graph 1: Coverage rate: contributors/working population by age (CMR and CNSS)}

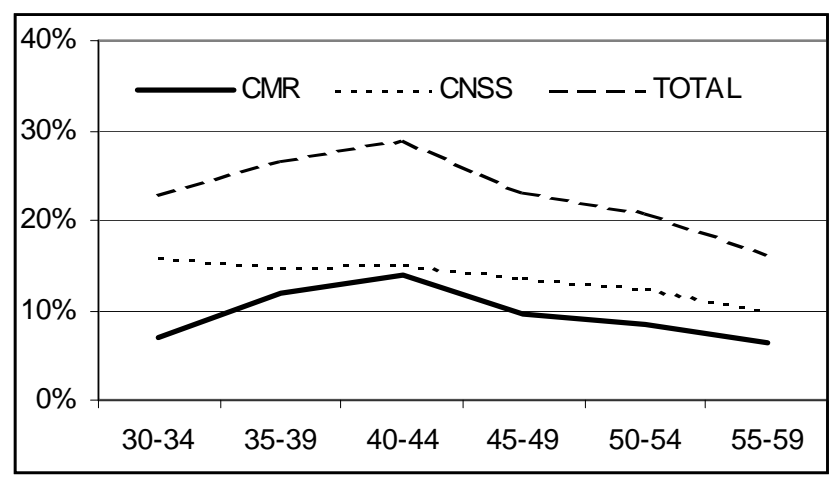

Source: Moroccan Economic Ministry Report

The second problem is the impact of demographic evolution on a pension system working as a PAYG one. According to official projections, the dependency ratio is expected to increase from 2010 to reach 60 percent in 2040 (see Graph 2). If all the other parameters are unchanged, this aging population will increase total pensions paid relative to total contributions, creating a financial disequilibrium. Even if certain regimes have accumulated important reserves and even if demographic evolution will create a pension system deficit in the medium term, reform is needed as soon as possible. Putting back the reform will increase the contribution effort for future generations.

\section{Graph 2: Dependency ratio evolution in Morocco: (retired population/20-59 working} population)

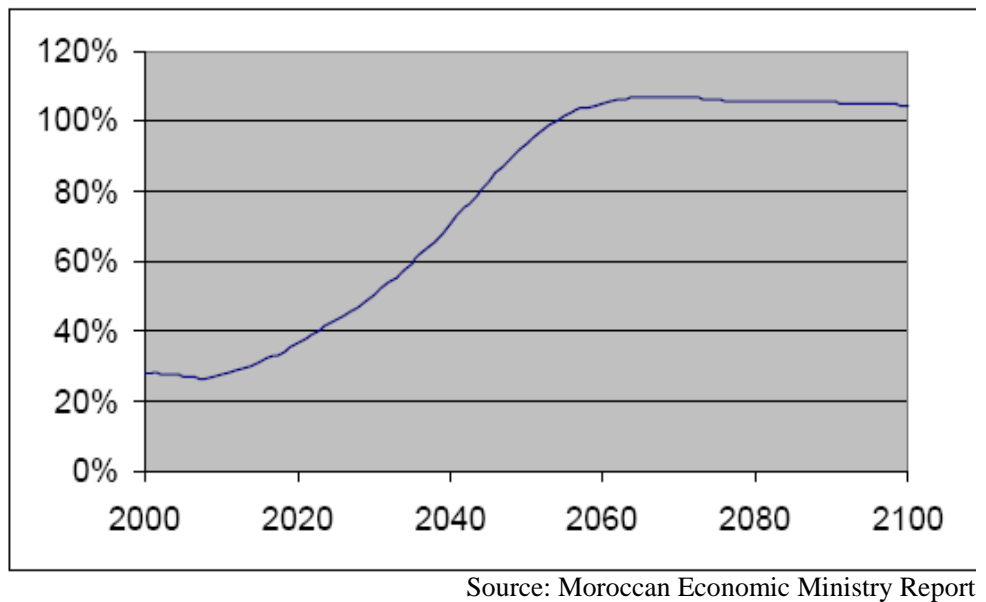

The third problem concerns pension indexation. There is no clear legislation concerning pension indexation in Morocco. According to an actuarial study from the economic ministry, indexation is evaluated at one third of the inflation rate. Pension 
indexation is an important issue since otherwise the purchasing power of retirees could decrease with time. This situation could lead to a consumption decrease, an increase of the gap between the active population and retired population and an increase of poverty.

\section{Tunisian pension system}

Tunisia's pension system seems to be simple, with two regimes: CNRPS (public sector) and CNSS (private sector). The CNSS is constituted by seven regimes organized through socio-professional categories.

RSNA (Regime des salariés non agricoles): it concerns the private sector employees except the agricultural sector. It is the most important regime in terms of number of contributors.

RSAA (Régimes des salariés agricoles amélioré): new regime for employees of the agricultural sector.

RSA (Régimes des salariés agricoles): regime for agricultural sector employees.

RTNS (Régimes des travailleurs non salariés): regime for self-employed workers.

RTFR : (Régimes des travailleurs à faibles revenus): regime for low-wage employees.

RACI : (Régimes d'artiste créateurs et intellectuels): regime for artists and intellectuals.

RTC: (Régimes des travailleurs des chantiers): regime for building sector workers.

RTTE : (Régimes des travailleurs tunisiens à l'étranger): regime for Tunisian workers abroad.

Table 3: The Tunisian pension system legislation

\begin{tabular}{|c|c|c|c|c|c|c|}
\hline & CNRPS & \multicolumn{5}{|c|}{ CNSS } \\
\hline & & RSNA & RSAA & RSA & RTNS & RTTE \\
\hline Retirement age & 60 years & 60 years & 60 years & 60 years & 65 years & 65 years \\
\hline $\begin{array}{l}\text { Minimum } \\
\text { contribution }\end{array}$ & 15 years & 5 years & 10 years & 10 years & 10 years & 10 years \\
\hline $\begin{array}{l}\text { Contribution } \\
\text { rate }\end{array}$ & $(7 / 9.7) \%$ & $(4.74 / 7.76) \%$ & $(2.5 / 5) \%$ & $(1.75 / 3.5) \%$ & $-/ 7 \%$ & $5.25 \%$ \\
\hline $\begin{array}{l}\text { Wage used to } \\
\text { pension } \\
\text { calculation }\end{array}$ & $\begin{array}{l}\text { Last wage } \\
\text { or average } \\
\text { of the } 2 \\
\text { better years }\end{array}$ & $\begin{array}{l}\text { Average } \\
\text { wage of the } \\
\text { last } 10 \text { years } \\
(\max 6 \\
\text { MGWI }^{2} \text { ) }\end{array}$ & $\begin{array}{l}\text { Average } \\
\text { wage of the } 3 \\
\text { or } 5 \text { last } \\
\text { years }(\max 6 \\
\left.\text { MGWA }^{3}\right)\end{array}$ & $\begin{array}{c}\text { Average } \\
\text { wage of the } 3 \\
\text { or } 5 \text { last } \\
\text { years (max } 2 \\
\text { MGWA) }\end{array}$ & $\begin{array}{l}\text { Average of } \\
\text { the declared } \\
\text { wage }\end{array}$ & $\begin{array}{l}\text { Average of } \\
\text { the declared } \\
\text { wage }\end{array}$ \\
\hline $\begin{array}{l}\text { Pension } \\
\text { calculation }\end{array}$ & $\begin{array}{l}2 \% \text { for the } \\
10 \text { first } \\
\text { years, } 3 \% \\
\text { for the } \\
\text { second } 10 \\
\text { years and } \\
2 \% \text { after }\end{array}$ & $\begin{array}{l}4 \% \text { for the } 10 \\
\text { first years, } \\
2 \% \text { for the } 20 \\
\text { years after }\end{array}$ & $\begin{array}{l}4 \% \text { for the } 10 \\
\text { first years, } \\
2 \% \text { for the } 20 \\
\text { years after }\end{array}$ & $\begin{array}{l}4 \% \text { for the } 10 \\
\text { first years, } \\
2 \% \text { for the } 20 \\
\text { years after }\end{array}$ & $\begin{array}{l}3 \% \text { for the } 10 \\
\text { first years, } \\
2 \% \text { for the } 25 \\
\text { years after }\end{array}$ & $\begin{array}{l}3 \% \text { for the } 10 \\
\text { first years, } \\
2 \% \text { for the } 25 \\
\text { years after }\end{array}$ \\
\hline
\end{tabular}

\footnotetext{
${ }^{2}$ Minimum Guaranteed Wage in Industry

${ }^{3}$ Minimum Guaranteed Wage in Agriculture
} 


\begin{tabular}{|l|l|l|l|l|l|l|}
\hline $\begin{array}{l}\text { Maximum } \\
\text { replacement } \\
\text { rate }\end{array}$ & $90 \%$ & $80 \%$ & $80 \%$ & $80 \%$ & $80 \%$ & $80 \%$ \\
\hline $\begin{array}{l}\text { Minimum } \\
\text { pension }\end{array}$ & $2 / 3$ MGWI & $\begin{array}{l}2 / 3 \text { of the } \\
\text { MGWI }\end{array}$ & $\begin{array}{l}50 \% \text { of the } \\
\text { MGWA }\end{array}$ & $\begin{array}{l}40 \% \text { of the } \\
\text { MGWA }\end{array}$ & $\begin{array}{l}30 \% \text { MGWI } \\
\text { or MGWA }\end{array}$ & $\begin{array}{l}30 \% \text { MGWI } \\
\text { or MGWA }\end{array}$ \\
\hline $\begin{array}{l}\text { Wage } \\
\text { indexation }\end{array}$ & $\begin{array}{l}\text { Coefficients } \\
\text { fixed yearly } \\
\text { by social } \\
\text { security } \\
\text { ministry }\end{array}$ & $\begin{array}{l}\text { Coefficients } \\
\text { fixed yearly } \\
\text { by social } \\
\text { security } \\
\text { ministry }\end{array}$ & $\begin{array}{l}\text { Coefficients } \\
\text { fixed yearly } \\
\text { by social } \\
\text { security } \\
\text { ministry }\end{array}$ & $\begin{array}{l}\text { Coefficients } \\
\text { fixed yearly } \\
\text { by social } \\
\text { security } \\
\text { ministry }\end{array}$ & $\begin{array}{l}\text { Coefficients } \\
\text { fixed yearly } \\
\text { by social } \\
\text { security } \\
\text { ministry }\end{array}$ & $\begin{array}{l}\text { Coefficients } \\
\text { fixed yearly } \\
\text { by social } \\
\text { security } \\
\text { ministry }\end{array}$ \\
\hline $\begin{array}{l}\text { Pension } \\
\text { indexation }\end{array}$ & $\begin{array}{l}\text { Indexed on } \\
\text { wages }\end{array}$ & $\begin{array}{l}\text { In percent of } \\
\text { MGWI } \\
\text { evolution }\end{array}$ & $\begin{array}{l}\text { MGWA } \\
\text { evolution }\end{array}$ & $\begin{array}{l}\text { MGWI } \\
\text { evolution }\end{array}$ & $\begin{array}{l}\text { MGWI or } \\
\text { MGWA }\end{array}$ & MGWI \\
\hline
\end{tabular}

The Tunisian pension system will essentially suffer from the aging population. Tunisia needs to reform a generous pension system because of an important decrease of the dependency ratio, which will affect the financial equilibrium of both the public and private regimes (see Ben Braham 2006 for an evaluation of the deficit). During the last years, a certain number of new regimes have been created in order to improve the cover rate. This reform was focused on "low wage" workers and some categories of self employed workers who were generally involved in the informal sector. These new contributors and the increase in contributions level will help to compensate, in part, the aging population impact. These reforms are not sufficient; the problem is still unresolved and needs an important parametric and structural reform.

The term generosity is always coming back when we speak about pension system situations in North Africa. This generosity could be justified by the low level of wages. In order to maintain a certain purchasing power in the retirement period, the replacement rates have to reach a high percentage of the last wage. This generosity was not a problem as long as the pension system was young and the dependency ratio was low enough. But, demographic evolution is creating an important problem: this generosity is not sustainable. Reforms are needed and in all the cases they will be unpopular. We try in what follows to evaluate this generosity through certain indicators.

\section{Career simulations and pension system generosity}

As we have noted above, pension systems in North Africa are considered to be generous. By using precise indicators, we can analyze this generosity and identify its source. In addition, we can make national and international comparisons. Based on the same career evolution, simulations allow us to compare the pension systems in the three countries. In order to measure the results' sensibility to the career profile, we choose three scenarios and present the results obtained in terms of generosity. Using each country's detailed legislation, 
we can make some comparisons of the pension obtained after the same career in Algeria, Morocco and Tunisia.

Simulation hypothesis:

- Initial gross wage (W) is 100.

- Contribution period T is 35 years; period choice is based on activity rates at different ages. We consider a career start age of 25 and a retirement age of 60 years (legal retirement age in most cases).

- Contribution rates are different from one plan to another and from one country to another.

We will take into account the most representative ones in each country (contributors' percent).

- Retirement period depends on life expectancy at 60 years in each country.

- Career profile: three scenarios of wage evolution are considered (in real terms):

Scenario 1: A constant evolution of 2 percent during the entire career;

Scenario 2: A constant wage during the fifteen first years, with an increase of 5 percent during the later twenty years;

Scenario 3: A constant wage during the ten first years, with an increase of 3.6 percent during the later twenty years and a constant wage after.

\section{Graph 3: Career profile scenarios}

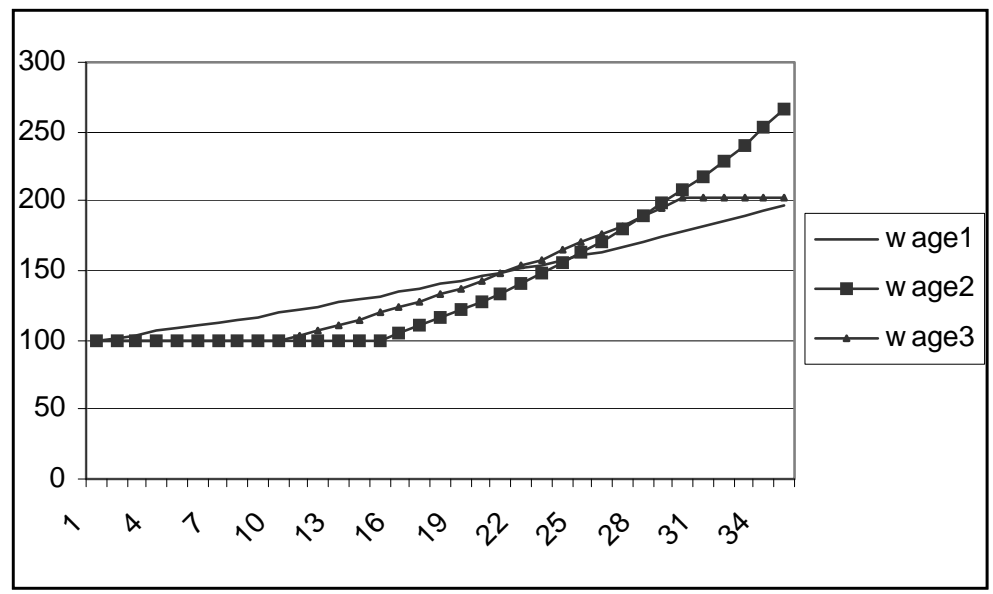

It is important to note that the three scenarios give the same average wage. These scenarios allow us to make two types of comparisons: the impact of career profile on the pension level in each country and for each profile to make international comparisons. 
Based on these hypothesis, we choose three indicators of retirement system profitability. ${ }^{4}$ This will allow us to analyse in a comparative way the generosity degree of pension system in Algeria, Morocco and Tunisia.

Notations are the following :

$\mathrm{Ci}$ : total contribution in the retirement system (employee + employer) paid in year $i$ (in constant dinars or dirhams).

$R$ : pension (in dinars constant).

$T$ : number of contribution years to the pension system.

$N$ : retirement period.

The first indicator is the recovery delay (D), defined as the necessary period for the retiree to receive exactly the total amount of her or his contributions.

$$
D=\frac{\sum_{i=1}^{T} C i}{R}
$$

The second indicator is the recovery rate (g), which represents the ratio between the total pension received and the total contribution.

$$
g=\frac{\sum_{i=1}^{N} R}{\sum_{i=1}^{T} C i}=\frac{N}{D}
$$

The third indicator is the actuarial return « $\mathrm{j}$ » usually called Internal Rate of Return. This indicator measures the interest rate that a worker should receive on her or his contribution in order to receive the same pension level offered by the PAYG system.

$$
-\sum_{i=0}^{T-1} \frac{C i}{(1+j)^{i}}+\sum_{i=0}^{N-1} \frac{R}{(1+j)^{i+T}}=0
$$

Using the legislation applied in each country, we present, in what follows, the results by country and by regime (the most representative regime has been chosen):

\footnotetext{
${ }^{4}$ Indicators presented by Vernière L. in “Questions retraite” no. 98-07-Janvier 1998.
} 


\section{A. Algeria results}

According to Algerian legislation, we present in what follows, the results for the CNR and the CASNOS. We take into account a life expectancy, at 60 years, equal to twenty years. Table 4 summarizes the results:

Table 4 : Generosity indicators of pension system in Algeria: CNR/CASNOS cases

\begin{tabular}{|c|c|c|c|}
\hline & $\begin{array}{l}\text { Scenario } 1 \\
\text { CNR (CASNOS) }\end{array}$ & $\begin{array}{l}\text { Scenario } 2 \\
\text { CNR (CASNOS) }\end{array}$ & \begin{tabular}{|l} 
Scenario 3 \\
CNR (CASNOS)
\end{tabular} \\
\hline \multicolumn{4}{|l|}{\begin{tabular}{|l|} 
Hypothesis \\
\end{tabular}} \\
\hline Contribution rate & $17.25 \%(15 \%)$ & $17.25 \%(15 \%)$ & $17.25 \%(15 \%)$ \\
\hline Average wage & 142 & 142 & 142 \\
\hline $\begin{array}{l}\text { Wage Annual Growth } \\
\text { rate }\end{array}$ & $2 \%$ & $2.82 \%$ & $2.04 \%$ \\
\hline Pension level & 155.65 & 191.31 & 170.2 \\
\hline \multicolumn{4}{|l|}{ Results } \\
\hline $\begin{array}{l}\text { Gross replacement rate } \\
\text { (last wage) }\end{array}$ & $76.92 \%(73.3 \%)$ & 72.73\% (64.8\%) & $80 \%(\mathbf{7 7 . 3 \% )}$ \\
\hline $\begin{array}{l}\text { Net replacement rate (last } \\
\text { wage) }\end{array}$ & 93.2\% (86.23\%) & $88.16 \% \mathbf{( 7 6 . 3 \% )}$ & 96.96\% (90.9\%) \\
\hline Recovery delay & 5.72 (5.22) & 4.44 (4.33) & $5.28(4.75)$ \\
\hline Recovery rate & 4.39 (3.55) & 5.65 (4.29) & 4.75 (3.9) \\
\hline Actuarial return & $5.47 \% \mathbf{( 5 . 7 9 \% )}$ & $6.6 \%(\mathbf{6 . 6 9} \%)$ & $5.88 \%(\mathbf{6 . 2 6} \%)$ \\
\hline
\end{tabular}

The CNR regime offers a higher replacement rate than CASNOS in the three scenarios. It is interesting to note that under the legislation used, the third career profile gives the best replacement rate (as in Morocco, see Table 5). The recovery delay is shorter for the CASNOS. This is explained by the lower contribution rate compared to CNR. Since the pension level in CNR is higher, retirees from this regime benefit in all three cases from a higher recovery rate. For example, in scenario 2, retirees from CNR will receive, during all the retirement periods, a total pension equal to 5.65 times their total contribution, whereas this ratio will reach 4.29 times their total contribution for the CASNOS. The last indicators from Table 4 show that actuarial return is higher in the CASNOS regime. The difference between the two regimes is more pronounced in the third scenario (0.38 percent). In addition, the second career profile offers the highest actuarial return (6.6 percent and 6.69 percent).

According to our simulations, actuarial returns in Algeria are higher than in Morocco but lower than the Tunisian ones (see Tables 5 and 6). We considered, in our simulations, the 
same career profiles in all three countries. This hypothesis allows us to make international comparisons. In fact, the wage levels are very different between the three countries.

Finally, we tried to compare actuarial return of pension systems to interest rates offered on saving accounts. This comparison is not really possible in Algeria since Islamic banks do not offer fixed returns in advance. Interest rates on saving accounts depend on bank financial results. So, we compared actuarial returns to the money market rate. This rate in December 2007 was fixed at 3.36 percent. This value is much lower than actuarial returns for all the regimes and all the scenarios.

\section{B. Morocco results}

We present, in what follows, the results for the Moroccan CNSS and CMR, which together represent 82 percent of total contributors. We consider a life expectancy, at 60 years, equal to 19 years. Since pension indexation is decided by CMR's board of directors, there is no possible way to calculate it. We took the last available value, which is 3 percent (nominal value). We didn't find any past values to analyze retirees' purchasing power progress. Table 5 presents the results:

Table 5 : Generosity indicators of the pension system in Morocco: CNSS/CMR cases

\begin{tabular}{|c|c|c|c|}
\hline & $\begin{array}{l}\text { Scenario } 1 \\
\text { CNSS (CMR) }\end{array}$ & $\begin{array}{l}\text { Scenario } 2 \\
\text { CNSS (CMR) }\end{array}$ & $\begin{array}{l}\text { Scenario } 3 \\
\text { CNSS (CMR) }\end{array}$ \\
\hline \multicolumn{4}{|l|}{ Hypothesis } \\
\hline Contribution rate & $11.89 \%(20 \%)$ & $11.89 \%(20 \%)$ & $11.89 \%(20 \%)$ \\
\hline Average wage & 142 & 142 & 142 \\
\hline $\begin{array}{l}\text { Annual growth rate of } \\
\text { wages }\end{array}$ & $2 \%$ & $2.82 \%$ & $2.04 \%$ \\
\hline Pension level & 155.65 & 191.31 & 170.2 \\
\hline \multicolumn{4}{|l|}{ Results } \\
\hline $\begin{array}{l}\text { Gross replacement rate } \\
\text { (last wage) }\end{array}$ & $65.3 \%(\mathbf{8 7 . 5 \% )}$ & $59.3 \% \mathbf{( 8 7 . 5 \% )}$ & 69.01\% (87.5\%) \\
\hline $\begin{array}{l}\text { Net replacement rate (last } \\
\text { wage) }\end{array}$ & 74.2\% (109.3\%) & 67.4\% (109,3\%) & 78.4\% (109.3\%) \\
\hline Recovery delay & 4.63 (5.82) & $3.75(\mathbf{4 , 2 8 )}$ & $4.21(5.60)$ \\
\hline Recovery rate & $3.47(2.76)$ & $4.29(3,72)$ & 3.81 (2.87) \\
\hline Actuarial return & $5.06 \%(4.17 \%)$ & 6.1\% (5.55\%) & $5.56 \%(4.44 \%)$ \\
\hline
\end{tabular}

In Morocco, the CMR seems to be more generous than the CNSS in terms of replacement rate, since for the same career the replacement rate is much higher in the CMR and could reach 109 percent. But, for the last three indicators of Table 5, the CNSS seems to 
be more generous. This is explained by the difference between the two regimes in terms of contribution rate. The CMR contribution rate is much higher than the CNSS one (see Table 2). In addition, the results are different from one career profile to another. In the CNSS, the third career profile (scenario 3) is the better one in terms of replacement rate. But in terms of recovery delay, recovery rate and actuarial return, the second career profile is the best.

Actuarial return varies between 5 percent and 6.1 percent for the CNSS and 4.17 percent and 5.65 percent for the CMR. This is another result showing the generosity of the pension system in Morocco. We can compare these rates to the interest rate offered in a classical saving account. The interest rate offered on saving accounts in Morocco varies between 2.41 percent and 3.76 percent. $^{5}$ These rates are under the level of actuarial return of PAYG retirement systems for all the scenarios.

\section{Tunisia results}

We calculate the three indicators for the Tunisian public regime (CNRPS) and the private one (CNSS). For the CNSS we only took into account the RSNA regime since it constitutes 75 percent of total contributors. Table 6 summarizes the results:

Table 6 : Generosity indicators of pension system in Tunisia: CNRPS/CNSS (RSNA) cases

\begin{tabular}{|c|c|c|c|}
\hline & $\begin{array}{l}\text { Scenario } 1 \\
\text { CNRPS (CNSS: RSNA) }\end{array}$ & $\begin{array}{l}\text { Scenario } 2 \\
\text { CNRPS (CNSS: RSNA) }\end{array}$ & $\begin{array}{l}\text { Scenario } 3 \\
\text { CNRPS (CNSS: RSNA) }\end{array}$ \\
\hline \multicolumn{4}{|l|}{ Hypothesis } \\
\hline Contribution rate & $16.7 \%(12.5 \%)$ & $16.7 \%(12.5 \%)$ & $16.7 \%(12.5 \%)$ \\
\hline Average wage & 142 & 142 & 142 \\
\hline $\begin{array}{l}\text { Annual growth rate } \\
\text { of wages }\end{array}$ & $2 \%$ & $2.82 \%$ & $2.04 \%$ \\
\hline Pension level & 155.65 & 191.31 & 170.2 \\
\hline \multicolumn{4}{|l|}{ Results } \\
\hline $\begin{array}{l}\text { Gross replacement } \\
\text { rate (last wage) }\end{array}$ & 80\% (83\%) & $80 \%(73 \%)$ & 80\% (87\%) \\
\hline $\begin{array}{l}\text { Net replacement rate } \\
\text { (last wage) }\end{array}$ & 96\% (95\%) & $96 \%(\mathbf{8 3} \%)$ & 96\% (100.3\%) \\
\hline Recovery delay & 5.32 (3.83) & 3.91 (3.20) & $5.11(3,49)$ \\
\hline Recovery rate & $3.24(4.51)$ & 4.42 (5.39) & $3.37(\mathbf{4 , 9 5 )}$ \\
\hline Actuarial return & $5.44 \% \mathbf{( 6 . 6 1 \% )}$ & $6.78 \%(7.5 \%)$ & $5.71 \%$ (7.1\%) \\
\hline
\end{tabular}

\footnotetext{
${ }^{5}$ Statistics from Groupement professional des banques du Maroc (GPBM).
} 
The results in Tunisia present a certain number of specific differences with Morocco and Algeria. First, the replacement rate in the CNRPS regime is not influenced by career profile. Secondly, in Morocco and Algeria, when one regime is more generous than another, it is true for all three scenarios.

In Tunisia, we can see from Table 6, that the CNSS:RSNA regime is characterized in scenario 1 and 3 by higher gross and net replacement rates than the CNRPS regime. This situation is inversed in scenario 2 since the CNRPS becomes more generous (80 percent versus 73 percent and 96 percent versus 83 percent). A career profile with an important evolution in the last years before retirement means higher contributions, which are not totally compensated in the pension calculation. As a result, the replacement rate decreases compared with scenarios 1 and 3. Concerning the three last indicators, scenario 2 gives the best results in terms of generosity for the two regimes, the CNSS:RSNA presenting more generous indicators than CNRPS. Return on a saving account in Tunisia is around 3.25 percent. This rate is much lower than the actuarial return of pension system for all the regimes whatever career profile we choose. This result will constitute an important question when we consider the introduction of pension funds beside the PAYG existing system. Could funded pension funds offer returns near those of a PAYG regime?

\section{Comparison between the three countries}

Graph 4 present a comparison between the three countries concerning average wage and average pension in the three countries in 2004. Graph 5 represents the GDP/capita in 2007.

\section{Graph 4: monthly average wage and} pension in US \$ PPP (2004)

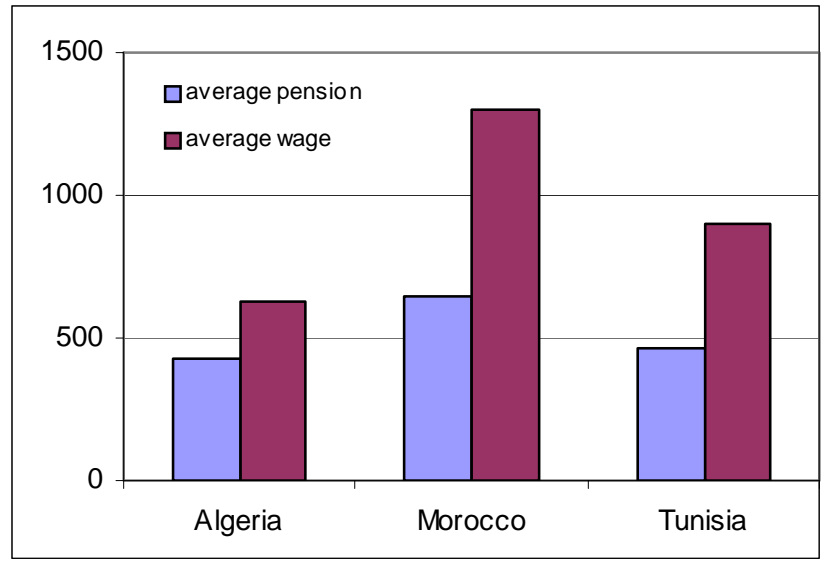

Source: Dupuis (2008)

\section{Graph 5 : GDP/capita US \$ PPP (2007)}

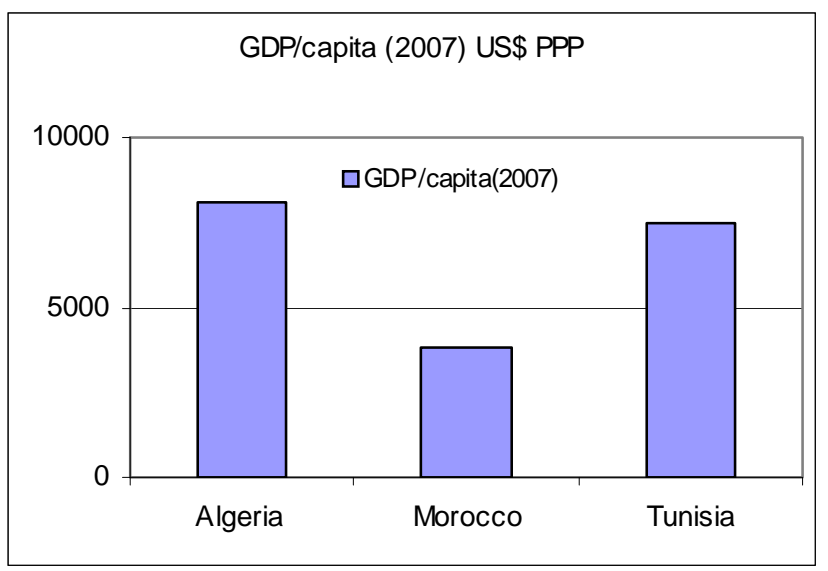

Source: World Bank (2007) 
Graph 4 and 5 show a paradoxical result. Algeria, which has the highest GDP/capita (in US \$ PPP) has the lowest average wage and pension level. With low average wage, the pension system must be very generous in order to maintain a certain level of consumption in the retirement period. So, the pension system generosity is often justified by low wages. On the other hand, Morocco has the highest average wage and average pension. In Morocco, legislation does not put any limit on the declared wage which is used in pension calculation. In addition, contribution to the pension system is not mandatory in the agriculture sector, which explains the low cover rate. So, the pension system seems to be a generous system which benefits a certain category of privileged workers. An important part of the active population is outside of the system. This result means that intragenerational distribution is very limited in this country.

\section{A. Which reforms?}

We saw above that pensions systems in North African countries are divided into many regimes. This kind of system is not really optimal. While Tunisia seems to want to maintain this organization, Algeria and Morocco are discussing creating an integrated system (all professions and all sectors). Arguments for a centralized system suggest lower administration costs, more transparency and equity and, finally, an easier labor mobility.

Concerning the impact of aging populations, the three countries are in different stages of reform planning and application. Morocco seems to be in a more advanced stage. A certain number of studies have been made and reform is concretely negotiated between social partners. Tunisia is in a planning stage where studies try to measure aging impact and to give some reform propositions. In Algeria, reform suggestions are just beginning to emerge. We didn't find any precise study on this issue.

There is a large theoretical literature indicating that there is no magic solution to maintaining the financial equilibrium of a PAYG system in the face of aging population. The principal choice is between parametric change of the PAYG regime and/or a structural reform by introducing a funded pillar.

\section{B. Parametric reforms}

The financial equilibrium of a PAYG system is represented by the following equation with a given average wage:

$$
\begin{aligned}
& \text { Total Contributions }=\text { Total Pensions } \\
& \mathrm{cr}^{*} \mathrm{~W}^{*} \mathrm{C}=\mathrm{P} * \mathrm{R}
\end{aligned}
$$


cr: contribution rate

W: wage

C: contributors

P: pension

R: retired

From (2) we can write: $\quad \mathrm{cr}=(\mathrm{P} / \mathrm{W}) *(\mathrm{R} / \mathrm{C})$

$$
\mathrm{cr}=\text { replacement rate* dependency ratio }
$$

When the dependency ratio increases, the only way to compensate is to reduce the replacement rate and/or increase the contribution rate (see equation 4). So, choosing between these possibilities depends on the characteristics of the pension system and the macroeconomic conditions of each country. It is important to note that there is no general solution to apply to any country. The specific conditions of each country will largely influence the pension reform.

In North Africa, reforms must take into account in each case the characteristics of the pension system. Even if the systems seem to be generous, we should ask if this generosity is necessary or not, and for whom? Is it coming from low contribution rates? From high replacement ratios? From a low retirement age? We saw in our case simulations that generosity in each regime comes from different parameters. In Morocco, for example, the CMR is more generous in terms of replacement rate and the way to calculate the pension level, while the CNSS is more generous in terms of return. In Tunisia, the situation is more complex. Generosity depends on regime and career profile, as well. In the RSNA regime, we can obtain 83 percent of the last wage in scenario 2 and 100.3 percent in the scenario 3 . In the first case, the net replacement rate is better than the one offered by CNRPS and in the second case, the situation is inversed.

One logical measure could be to increase the legal retirement age, since life expectancy is continuously rising in the three countries. But this measure is not sufficient. It should be accompanied by other reforms. Contribution rates could be increased in regimes where they are relatively low. All the parametric reforms will depend on negotiations between government and workers unions. Empirical studies, especially in Tunisia and Morocco (Ben Braham, 2008; Report of Economic Ministry 2007) show that parametric solutions are not sufficient to maintain the financial equilibrium of pension systems in the long run. So, structural reforms are needed as well.

\section{Structural reforms}


As it is noted by the World Bank, there are two main advantages of structural reforms. They could help to resolve the problem of aging and they could create positive effects for the whole economy, in terms of reducing labor market distortions and developing financial markets. But, to be well undertaken, this reform needs a certain number of conditions. Its application in North African countries requires that these countries have the minimum financial structure necessary and the human capital to manage well the accumulated funds. Morocco and Tunisia have financial markets developed enough to begin the implementation of such reform. Another point is important to note. Pension systems in North Africa are characterized by excessively high actuarial returns (see last indicators in Tables 4, 5 and 6). Private pension funds will have to reach relatively high return levels in order to offer pensions high enough to be compared to those offered by PAYG systems.

\section{Conclusion}

Pension systems in North Africa suffer from a certain number of problems. One is their internal organization. The existence of several regimes increases administration costs. Another problem deals with coverage, even if disparity exists between the three countries. Morocco's private sector, for example, is characterized by very low coverage rate. This situation could be paradoxical since the pension system is very generous and then should be more attractive. This situation is mostly explained by low wage level and a lack of information, specifically in rural areas. Tunisia is making important efforts in terms of firmer control. This policy seems to be efficient since Tunisia has the highest coverage rate in North Africa.

Finally, an aging population is going to create serious problems in terms of financial equilibrium to systems working exclusively as PAYG. The high degree of generosity obtained in our simulations are not sustainable. High replacement rates and high actuarial returns could not be promised with the low level of contribution rate and retirement age. Our simulations do not give the real replacement rates since they are based on fictive cases. But, the increase of coverage and economic growth in these countries means longer career and higher wages. Then, replacement rates will converge to those obtained in our simulations.

Pension systems need parametric and structural reforms. The first type of reform is necessary to lighten the burden on pension system and to be well calibrated with social evolution. Increasing the contribution rate when it is possible and increasing the retirement age when life expectancy has increased seem to be a logical way to maintain the financial 
equilibrium of the pension system. The second type of reform has the advantage to constitute, in part, a solution against aging populations and to promote economic growth, as well. So, this type of reform could be integrated with all the reforms which have the objective to develop an open market economy. This reform will be not be easy to undertake for two reasons: the first one concerns the return that pension funds could offer. This return will be compared to the high actuarial return offered by the PAYG system, which is actually higher than the return of financial products, in the three countries. The second reason is the required financial market development. Morocco and Tunisia are making efforts to develop their financial market. So this reform will be possible in the short term. In Algeria, much more effort is needed to develop the financial market and to adapt the idea of a pension fund with Sheria. ${ }^{6}$

\footnotetext{
${ }^{6}$ Sheria is the body of Islamic law. It deals with many aspects of daily life including politics, economics, banking and social issues.
} 


\section{Bibliography}

Ben Braham M. (2008), “Impact de l'introduction dose de capitalisation en Tunisie: simulation à l'aide d'un modèle à générations imbriquées », Economie et Prévision, $\mathrm{N}^{\circ} 180$ 181.

Dupuis J.M., El Moudden C., Petron A. (2008) « Les systèmes de retraite au Maghreb: une première analyse», report for the French Labour Ministry.

Moroccan Economic Ministry (2001), "Scénario de réforme pour le système de retraite marocain,” Actuarial Report, December 2001.

Robalino D. A. (2005), "Pensions in the Middle East and North Africa: time for change”, the World Bank, Washington DC, 284p.

Rutkowsky M. (2007) “MENA pension system and pension system objectives”, World Bank working paper.

Verniere L. (1998), “Les indicateurs de rendement et de rentabilité de la retraite”, Questions retraites, n98-07. 